\title{
POETRY, CONSTITUTION AND THE LIBERAL TRIENNIUM: ENGLISH, GERMAN, ITALIAN, PORTUGUESE AND FRENCH LITERARY TEXTS ON THE SPANISH LIBERAL REVOLUTION (1820-1823)
}

\author{
José Ruiz Mas \\ Universidad de Granada
}

\begin{abstract}
Recensión de / Review of
- Ingrid Cáceres Würsig and Remedios Solano, Kings and peoples German Poetry of the Liberal Triennium. Analysis and Bilingual Annotated Corpus. Ediciones Universidad de Salamanca, Colección Aquilafuente $n^{\circ}$ 273, Salamanca, 2019, 334 pp.
\end{abstract}

- Gabriela Gândara Terenas and Beatriz Peralta García, Tell the Spaniards: Portuguese Poetry of the Liberal Triennium. Analysis and Bilingual Annotated Corpus. Ediciones Universidad de Salamanca, Colección Aquilafuente $n^{\circ} 274$, Salamanca, 2019, 311 pp.

- Cristina Clímaco and Lola Bermúdez Medina, Spain's Tears: French Poetry of the Liberal Triennium. Analysis and Bilingual Annotated Corpus. Ediciones Universidad de Salamanca, Colección Aquilafuente $n^{\circ}$ 275, Salamanca, 2019, 607 pp.

- Vicente González Martín and Mercedes González de Sande, A desired Constitución: Italian Poetry of the Liberal Triennium. Analysis and Bilingual Annotated Corpus. Ediciones Universidad de Salamanca, Colección Aquilafuente $\mathrm{n}^{\circ}$ 276, Salamanca, 2019, $605 \mathrm{pp}$.

- Agustin Coletes Blanco and Alicia Laspra Rodriguez, Romantic Land: English Poetry of the Liberal Triennium. Analysis and Bilingual Annotated Corpus. Ediciones Universidad de Salamanca, Colección Aquilafuente ${ }^{\circ} 277$, Salamanca, 2019, 476 pp.

Palabras clave: Romanticismo, Trienio Constitucional, (1820-23), Proyección y recepción cultural, Literatura política y de guerra, Edición y traducción académica.

Key Words: Romantic Period, Spanish Constitutional Triennium (1820-23), Cultural Projection and Reception, Political and War Literature, Academic Edition and Translation.

Few historians nowadays would fail to label the Spanish absolutist Bourbon King Ferdinand VII anything but "el rey felón". He is commonly perceived by historiography both home and abroad as being undeniably responsible for giving rise to major civil unrest in Spain from 1820 to 1823 as well as exercising cruel repression in the years ensuing, to say the least. Ferdinand VII's post-PeninsularWar tricks had begun when he swore loyalty to the liberal 1812 Constitution of Cádiz -anything for a throne. Soon after, he did not hesitate to encourage 
France's military invasion of Spain in order to impose his real vocation on his Spanish subjects: an absolutist monarchy. This brief $1820-23$ period, a most peculiar one in Spain's turbulent 19th-century, began in 1820 with Riego's pronunciamento against the king's absolutist regime, which obliged the monarch to comply with the liberal 1812 Constitution for three years. In 1823, however, the French invasion of Spain (the "Cien Mil Hijos de San Luis"), led by Angoulême, was used by Ferdinand VII to reinstall his absolutist ways. The Spanish royal felony and the subsequent liberal reaction in 1820 had a huge impact on a sensitive post-Napoleonic Europe, which had also suffered its own share of political and ideological wars. The Spanish rebellion against absolutism was regarded as a model and guide to follow, especially in the nations governed by absolutist monarchs. Myriads of poems and other literary/political texts in different European languages of varying literary quality, but of powerful proliberal or counter-revolutionary sentiment, were written and published between 1820 and 1823 in journals and periodicals to praise and support both the Spanish liberal revolution and their respective liberal revolutions, or to defend their absolute monarchies.

No less than ten members of Poetry'15 (www.unioviedo.es/poetry15/), an I+D Project of the National Programme for the Encouragement of Scientific and Technical Research of Excellence (Reference no. FFI2015-68421-P) titled "Poesía y Trienio: Textos poéticos ingleses, alemanes, italianos, portugueses y franceses sobre la revolución liberal española (1820-1823). Edición, traducción y estudio (Proyecto POETRY'15)" and financed by the Spanish Ministry of Science, Innovation and Universities and the University of Oviedo, led by Professor Agustin Coletes Blanco, have recently authored five books with the purpose of rescuing from oblivion the numerous long-forlorn poems and other literary texts which channelled public opinion on Spanish affairs in a number of European countries (Germany, Portugal, France, Italy and Britain), during the so called "Liberal Triennium" (1820-23) of Spain's Ferdinand VII's reign. The Poetry'15 Project's five volumes, published simultaneously in December 2019, are Reyes $y$ pueblos: poesia alemana del Trienio Liberal, by Ingrid Cáceres Würsig (Universidad de Alcalá) and Remedios Solano (Johannes Gutenberg-Universität, Mainz); Contadles a los españoles: poesía portuguesa del Trienio Liberal, by Gabriela Gândara Terenas (Universidade Nova de Lisboa) and Beatriz Peralta Garcia (Universidad de Oviedo); El llanto de España: poesía francesa del Trienio Liberal, authored by Cristina Climaco (Université de Paris 8) and Lola Bermúdez Medina (Universidad de Cádiz); La Constitución soñada: poesía italiana del Trienio Liberal, by Vicente González Martín (Universidad de Salamanca) and Mercedes González de Sande (Universidad de Oviedo), and Romántico pais: poesía inglesa del Trienio Liberal, by Agustín Coletes Blanco and Alicia Laspra Rodriguez (Universidad de Oviedo), i.e., numbers 273 to 277 of the Aquilafuente collection published by the Universidad de Salamanca. Indeed, the whole set comprises a total of 2,500 pages, an academic feat that provides a faithful idea of the mammoth research successfully realised by the scholarly team of Oviedo's Poetry'15 project, formed by experts from universities of four different countries.

Each of the five books can proudly boast about fulfilling three academic axes, namely: a) firstly, the historical research carried out to locate the different literary texts written in the three years of liberal rule, mostly consisting of poems written in German, Portuguese, French, Italian and English originally published 
in hundreds of periodicals at the time; b) secondly, the critical study of these texts, most being poems of varying literary quality but containing extensive propagandistic, cultural and historical information; c) and thirdly, the academic translation of literary texts of varying philological difficulty. The momentous publication of these five monographies and critical bilingual editions demonstrating the influence of the Spanish "Liberal Triennium" on European literature and politics could not have been timelier: 2020, the ominous year that the coronavirus has shown its ugly head worldwide, celebrates the Bicentenary of the beginning of the Spanish revolution of 1820-23.

Cáceres Würsig and Solano's Reyes y pueblos: Poesia alemana del Trienio Liberal begins with the description of the political and cultural atmosphere of the Germanic Confederation (Deutscher Bund) in 1820. Riego's rising in Spain and the subsequent short-lived re-establishment of the liberal 1812 Constitution of Cádiz in absolutist Spain inspired fresh airs of hope for liberalism in part of the German-speaking society. However, the other half showed fear that revolution might bring about anarchy and war, as had been the case of the French Revolution, especially after Kotzebue's murder in 1819 by a liberal student and the vehement pressures exerted by the students' organizations. Repression and strict censorship was established by the so-called Karlsbard Decrees (Karlsbader Beschlüsse) and the Germanic Confederation authorities -especially Metternich's Austria. They scrutinized all periodicals of the period and banned texts which encouraged rebellion of any sort against the order established by the Restauration, or mentioned news related to Spain, whether pro-liberal or proabsolutist. Due to these repressive measures, the German Romantics found it difficult to follow the news coming from Spain closely, and their works do not reveal the Spanish liberal influence as intensively as in some other European countries. Pro-governmental journals did not provide positive views about the Spanish liberal revolution and those journals which were nevertheless tolerated Oppositions-Blatt oder Weimarische Zeiting, Teutscher Beobachter, Allgemeine Zeitung and Minerva- looked for alternative and subtle or disguised ways to favour only moderate liberal ideas, or limited themselves to informing their readership with the upmost objectivity and neutrality about the expected French invasion of Spain. With evident restrictions, Spanish liberal protagonists such as Riego, Espoz y Mina, the Cádiz Constitution, etc., became mythical figures in the liberal German imagology.

When Cáceres Würsig and Solano perceived that a good deal of literary production on the Liberal Triennium continued to be published in the Germanic Confederation up until 1830, due to the fact that the censorship laws had become more lax on free publishing on things Spanish after 1823, they extended their collected corpus to that year. The book's authors have divided the 38 texts uncovered, analysed and translated into a) poems inspired by episodes of the Spanish revolution written by Chamisso, von Platen, Müller, Hauff, Grillparzer and Immermann between 1820 and 1830, which show how Riego was the predominant figure, praised and mystified, and how Ferdinand VII was the demonized one; b) poems published either posthumously (Chamisso, Müller, Hauff, Grillparzer, Grabbe), or camouflaged inside other innocent-looking texts (such as Heine's allusions in his drama Almanzor), or left in their original Spanish version (to avoid censorship), or presenting content as allegories. Cáceres Würsig and Solano have also included two prose texts, a scene from Heine's tragedy 
Almanzor and another one from Grabbe's comedy Scherz, Satire, Ironie und tiefe Bedeutung and have not therefore limited their corpus merely to poetry. Neither have they forgotten to include texts by absolutist sympathizers, such as Friedrich Schlegel. As Cáceres Würsig and Solano reveal in their book, the ideological struggle between monarchy/liberalism/constitution/nationalism provided the German-speaking peoples in the first third of the $19^{\text {th }}$ century with abundant food for thought on the political regimes and institutions that they wished to adopt for the future: whether there should be a monarchy or not, whether there should be a Parliament or not, whether there should be a Constitution or not, and even whether the king should have limited political powers or not.

Gândara Teneras and Peralta García's Contadles a los españoles: Poesía portuguesa del Trienio Liberal depicts the powerful impact that the Spanish liberal revolution had on the poetry written and published in Portugal in the 1820-23 period. They begin the book by thoroughly studying the poetic production written in Portugal and the strong inspiration that the Spanish Liberal Triennium had aroused in it. The authors have analysed in depth the selected Portuguese poems (54, plus 8 in Spanish), their authors and the journals where these saw the light within their appropriate cultural and historical framework. They have also translated the selected corpus of poems into Spanish and examined it from a political and historical perspective. They explain the features of the Portuguese poetic production in 1820-23 by insisting on the idea that, although the country's political and ideological panorama was indeed affected by the Spanish liberal revolt, like any other European country, Portugal interpreted that influence according to its own distinctive cultural, historical, and national circumstances. These could be listed as the flourishing of the Portuguese pre-romantic arcadismo; the long absence of the Portuguese royal family due to their earlier self-exile in Brazil; King D. João VI's proclamation of the Portuguese liberal Constitution in 1822; the "official" start of Portuguese Romanticism in 1825 thanks to Almeida Garrett's poem "Camões"; the abundant anonymous poems published as part of the literary output produced in the 1820-23 span of time; the relatively high number of Portuguese poems in favour of absolutism and King Ferdinand VII; the soaring increase in the number of journals founded in the brief span of three years, up to 112 new newspapers, both pro-liberal and proabsolutist; the easy flowing of writings in both languages across the frontier of the two neighbouring countries; D. Miguel's counter-revolution of Vila-Francada in 1823 for the reestablishment of an absolutist monarchy and King D. João VI's subsequent moderate rewriting of the liberal Constitution; the declaration of the Trienio Liberal Vintista that proclaimed the liberal revolution in Porto; the overt admiration of Spain's revolution and its protagonists depicted in Portuguese poetry as an excuse to exalt their own Portuguese heroes and the ideas of the Trienio Vintista; the rise of the idea of iberismo whereby the two heroic and brave liberal countries (Spain and Portugal) should become one, etc.

Clímaco and Bermúdez Medina's El llanto de España: Poesía francesa del Trienio Liberal concentrates on the French poetic production published from 1820 to 1823 as a result of the influence of the Spanish liberal revolution. In these three brief years, the French literary and propagandistic corpus embraced the clash of the different powerful and traumatic political undercurrents that still ran wild in post-revolutionary and post-Napoleonic France. Indeed, the Spanish liberal revolution of 1820 reopened uncured scars in France: the French 
Revolution and its period of Terror and the Napoleonic wars were too recent and too intensely interwoven in the minds of the French, and the Restauration han been built on still unstable foundations. Whereas King Louis XVIII's constitutional monarchy and France's 1814 Charte constitutionnelle had by 1819 given the country political balance, the assassination of the royal heir (the duke of Berry) and Spain's liberal airs destabilized the country's precarious political state in 1820. The immediate consequence of this new flow of liberal ideas coming from beyond the Pyrenees was that France saw herself once again divided into nostalgic supporters of the Ancien Regime or counter-revolutionaries (or pointus), liberals, and republicans. The corpus of poems collected and translated by Clímaco and Bermúdez Medina, 67 poems in total, most of mediocre literary quality except for those penned by Victor Hugo and Alfred de Vigny, clearly transpire those tensions as well as the French people's high political and civic commitment to their search for modernity.

In order to show the evolution of the impact of the Spanish Liberal Triennium in the French poetry of the period, the book's authors have opted for a chronological presentation of the selected poems. Indeed, two distinct stages have been perceived by Climaco and Bermúdez Medina in the French output. The first is a transitional period of doubt and uncertainty, characterised not only by doctrinal/ideological clashes between counter-revolutionaries and liberals in the backdrop of the Spanish revolution (1820-21) but also by a greater interest in the Greek struggle for independence from the Ottoman Empire than in Spain. However, a greater bulk of political poems on Spain were produced in the second period, spanning 1822-23, two years deeply marked first by the closing of the Franco-Spanish frontier due to an epidemic in Barcelona; secondly and above all, by Angoulême's military intervention in Spain in 1823, which was started following the orders of the Congress of Verona. As a result of that, Ferdinand VII was reestablished on the Spanish throne as a fully-fledged absolutist king. Spain's circumstances became the excuse to give free rein to the old French confrontations between supporters of the Ancien Regime and supporters of constitutional monarchy. French newspapers now printed their international items with headlines of Spain on their front pages and literary texts on Spain on their last pages and thus permanently kept the Spanish theme in the foreground of French society's interests, especially in 1823. The successful French intervention in Spain of Angoulême's troops was used by the French regime as a propagandistic boost to scream about the necessary stability of monarchy and celebrate French national sentiment and cohesion.

González Martín and González de Sande's La Constitución soñada: Poesía italiana del Trienio Liberal focuses on the impact that the Spanish "Liberal Triennium" had on the political, cultural and literary panorama of a pre-unified Italy. Italians took the Spanish liberal aspirations in 1820-23 as a model to copy in their endeavours for their long-wished-for unification and definitive liberation from foreign powers with absolutist regimes. Italian poetry enthusiastically transmitted through flyers or pamphlets the new values and ideas arriving from Spain's revolution despite the existing harsh governmental censorship. The general tone of the poetry produced in the Italic Peninsula was one of admiration for the Spanish people and of Spain, the paese di libertà. The Italian intellectuals, secret societies (Carbonari in the south, led by the charismatic General Pepe, and Federati in the north) and even the army itself encouraged revolution and the call 
to arms for freedom. The monarchs of the united kingdom of the Two Sicilies (formed by Sicily and Naples) and the kingdom of Sardinia and Piedmont even swore the 1812 Cádiz Constitution in 1820 and 1821 respectively, albeit pressed by the vehemence of their people. Unfortunately the constitutional reign of the Two Sicilies lasted only one year due first to the reluctance of Ferdinand I to be constitutional (having been forced to do so by the surrounding pro-liberal atmosphere); secondly to the Sicilians' nationalistic struggle for independence from Naples; thirdly to the opposition of the Holy Alliance to allow the south of the Italic Peninsula to turn to constitutionalism, and fourthly to the Austrian occupation of Naples and Sicily. González Martín and González de Sande also explain the process of the Spanish-inspired constitutionalism of Piedmont and Sardinia, on which the Spanish diplomats happened to exert a major influence. The Piedmontese revolutionaries wished to keep Austria's pressure at bay but the treacherous flight of the regent Carlos Felix (who had earlier reluctantly sworn the Spanish constitution) precipitated the collapse of the newly-formed liberal government and led to the invasion of Austria: the duration of the Spanish Constitution in Piedmont and Sardinia lasted a mere few months.

González Martín and González de Sande have dedicated the first and longer part of the book to the translation and analysis of the poetry corpus published in the Two Sicilies, dominated by the enthusiastic figure of Gabriele Rossetti and the heroic participation of women poets and revolutionaries such as "Giuseppina" and Cecilia de Luna-Folliero (of Spanish ancestry). The second part of their volume is dedicated to the poetry produced in Piedmont and Sardinia (and to a lesser extent in Lombardy-Veneto), then subjugated by Austria, more moderate and more reflexive than the southern Italian states and more inclined to produce essays than poems. This second part was dominated by the poetic production of Alessandro Manzoni, Amedeo Ravina and Giovanni Berchet. González Martin and González de Sande dedicate a third part of their book to the poetic output of the Italians in exile (mainly in England, Malta and Spain), and also to that written in the Papal States and in the dukedom of Tuscany. The book authors have selected and translated 64 items altogether (both poems and essay excerpts) where the revolutionary movements in Italy under the influence of the Spanish "Liberal Triennium" appear at their best in the different independent kingdoms and dukedoms of the Italic Peninsula during the 1820-23 period, covering their initial success and their final disappointment.

In Romántico país: Poesía inglesa del Trienio Liberal Coletes Blanco and Laspra Rodriguez have successfully explained the passion conveyed by the British Romantic poets of the time about the political situation in Spain in the 1820-23 span. The book authors begin by describing the British historical and cultural highlights of the period: the so-called Peterloo Massacre (1819), the impact of Spain's "Liberal Triennium" on George IV's and Wellington's Britain, the United Kingdom's role in the international concert in 1821-22, the Verona Congress and the Madrid talks (1822), events that anticipated or culminated in the well-known final chapters of Spain's failed liberal revolution. These included the unopposed French military invasion, Riego's shameful execution and the vindictive repression on the liberal Spaniards, many of whom exiled themselves to England to save their lives. Coletes and Laspra have employed varied corpora of letters, narrations, laws, diaries, annual registers, war dispatches, newspaper and journal articles and printed illustrations, engravings and caricatures to explain 
the complex Anglo-Spanish political and literary relations in the turbulent three years of the Spanish revolution. As a result of their thorough search of journals, broadsheets, pamphlets and books they have managed to find a corpus of 229 English poems and translate a selection of 69, some of which were written by Romantic poets of the caliber of Lord Byron, P. B. Shelley, Felicia Hemans, Edward Bulwer-Lytton, Thomas Moore, Lord Holland, Leigh Hunt, John Gibson Lockhart and the odd prominent journalist such as Thomas J. Wooler.

Coletes Blanco and Laspra Rodriguez have divided the revolutionary period into three stages. The literary production written in each of these stages gives ample information about the evolution of the perception of the Spanish revolution in Britain. The first stage (1820-21) includes poems meant to encourage British liberals and radicals to reject monarchic despotism, just like the Spaniards had done through Riego's revolt against King Fernando VII, in order to embrace the prospect of an ideal country favoured by peace, liberty and love. In the second stage (1822-23), the English poetic production possesses a higher literary quality and the authorship of the poems is more openly declared; however, a slight touch of pessimism can be felt between the lines, for the initially successful liberal revolutions in the Italic Peninsula have by now collapsed, despite those initial success and optimism. However, Whig and radical poets in Britain still make fun of the prospective invading French army to be led by Angoulême and of the comfortable position of neutrality taken by the British government. They also try to press for British intervention in Spanish affairs, but to no avail. The third stage of the British poetic production includes compositions published in 1823. With Angouleme's successful entry in Madrid and Cádiz, the Spanish revolution comes to an end. The British satirical dart is now addressed to the Spanish Bourbon dynasty and its praise is reserved for exalting the Spanish exiled liberals who have managed to escape Ferdinand VII's cruel repressive claws.

A total of three hundred texts (most of them poems) collected in the five volumes have been selected, edited, translated into Spanish and analysed by the ten authors of the series. Most of them have never been published before in any scholarly edition. They have been also translated for the first time into Spanish. The shared features of all the translated corpora are, on the one hand, the philological care employed by the translators in their faithful rendering of the original messages into Spanish. They have attempted not to distort any of the Spanish versions of the poems in order to avoid risking the loss of the poets' primary intentions or the poems' intrinsic value as historical documents. The volume authors/translators have had to deal with keeping the balance between the accurate rendition of the poems whilst endeavouring to remain faithful to their poetic beauty and propagandistic intentions. The fact that the five volumes present bilingual editions of their literary corpora allows any studious reader to check the reliability of the translations. On the other hand, great merit should be given to the scholars' search of items, as these are usually preserved in library shelves abroad and more often than not in broadsheets, pamphlets, journals and books which are not easily accessible. Not only are the five books of great interest to Spanish historians, philologists and literary critics specialized or initiated in the "Liberal Triennium" of Ferdinand VII's reign, but also to scholars in Germany and Austria, Portugal and Brazil, France, Italy, Britain and Ireland investigating the same span of time. This collection now offers the world and any historical and literary study of the Romantic period in the aforementioned countries of Europe a 
necessary enlarged corpus of propagandistic texts in verse devoted to the 182023 constitutional period.

Fecha de envío / Submission date: 23/10/2020

Fecha de aceptación / Acceptance date: 3/01/2021 